\title{
Dakwah and Social Concern
}

\author{
Budi Suprapto \\ University of Muhammadiyah Malang, Indonesia \\ spbudhi@gmail.com
}

\begin{abstract}
The focus of the study was to determine the influence of the dash on dakwah communication message towards the behavior of social concern. This study also involves 3 moderator variables, namely the activity of forwarding dakwah message interpersonally, reference groups, and using of mass media. Through Moderated Regression Analysis (MRA) test, the obtained results are that the three moderator variables serve to reinforce the influence of dakwah message toward social concern. Even based on the results of $t$-test, the role of reference group variable was greatest than others. The objects of this study were 414 people. They were participants in the dakwah (recitation) activity held by Muhammadiyah and Qur'an Tafsir Council in the former residency of Surakarta, Central Java, Indonesia.
\end{abstract}

Keywords: Dakwah communication dash, forwarding message interpersonally, media, reference groups, and social concern.

\section{INTRODUCTION}

If dakwah is presumed as a movement of social change and empowerment, then dakwah is a system of very important movement in the history of Islamic civilization. Dakwah can be seen as the facility or activator for the process of directed and planned social change with the aim of forming individuals, families, and societies as well as the world civilization blessed by God [1].

As a movement for change, conceptually dakwah activity has two definitions, namely a) the process of delivering a message containing the Islamic percepts and b) inviting people into a process toward the improvement of the life quality to be better. Basically, both of them are inviting or influencing mind by resuscitating, directing, and guiding people to behave in accordance with the universal truth of the values derived from Islamic percepts [2]. This means that dakwah is a communication process transforming the values of the Islamic percepts in order to build a worldview in every human being.

One's worldview to the faced reality will determine the level of social awareness (social consciousness). Worldview and social concern are the two things, which become the basis for a person in doing self-identity and social identity [3]. The realization of religious concept is the birth of consciousness toward the highest social values. According to him, the form of consciousness meant is appreciate, being active, and uphold the highest social values. In Ames' view, religion should be placed as a source of the highest moral and social values in modern society. When religion becomes a source of the highest morals, the religious values will be the choice of the identity on every adherent's consciousness.

Based on the statement written above, it can be made the definition of social consciousness as a condition in which a person becomes aware to the social problems like as the difficulty of obtaining public resources, suffering, injustice, marginalization (marginalizing), and other similar conditions, to take part in order to find a way out of these problems.

The definition above is in line with Greene and Kamimura [4] that social consciousness is one of the key elements for realizing social action. According to them, social consciousness is the power of booster inside a person to dare to: a) be firm against social injustice, b) raise societal consciousness on the environment, c) encourage tolerance and mutual respect for the differences related to race or religion; d) only use the goods produced by factories which hold strong ethics.

Back to the discussion about the relationship between religious values and social consciousness, it is proven in Western society known with a secular ideology though, religious values are still an important factor, when interpreting social reality as well as in determining attitudes toward social issues they face in today's postmodern era. Therefore, mainly when they will take part in solving social problems requiring voluntary activity (voluntarily), they prefer to join a religious organization rather than other institutions. That although American society's belief toward public companies, especially royal institutions continued to decline since the 1950s, but their support for religious activity remains high. Consistently, their belief in religious organizations and religious leaders were higher than the courts, congress, banking, public education, mass media, or the company [5].

Even religious organization is the most preferred place by Americans to join as a volunteer. Being a volunteer is a form of social concern, which has very high value, because they must sacrifice the possessions, mind, and soul for the sake of others who are suffering due to various reasons. People's activity belonging to the group of volunteers who are affiliated to religious organizations is a form of the most dominant social concern [6].

On another occasion, [7] - [8] also found that the association of church networks is a combined form of groups and individuals to bind themselves. The networking activity of this church organization can influence and build their members' worldview and social behavior. Within this network, social and political issues also gain significant attention, in which the church opinion on that matter becomes the main reference. The decision of the church as well as proposed ideas that come 
from the churches they belong to involving the issue of society and public interest is delivered through a network of communication between them. Here, the group serves as a reference for the attitudes and behavior of its members.

On the other hand, there are research findings, which prove the contrary, namely the higher the involvement in religious activity is, the higher the understanding and belief in religion are. However, it is precisely negatively associated with the increase of social concern. Nisbet and colleagues had tested these relations by placing some religious behaviors as independent variables and social capital namely the social and political beliefs as the dependent variables. Religious behavior tested by Nisbet includes three dimensions. They are a) the frequency of the attendance to the church and the involvement in the networking organization of the church as religion's associational dimension, b) the level of understanding toward the scriptures (Bible) as a religion's cognitive dimension; c) the membership to organizations, groups or particular religious beliefs as the dimension of sectarian affiliation (denominational affiliation). Once again, thesaid three dimensions, both separately and together, are negatively related to social trust, social participation and political participation [9]

The evangelical of Protestant, which is assumed to have a high level of religiosity, does not have the consciousness to the existing social reality. They tend to be conservative and doctrinal in behaved and prioritize the services for the group [9] - [10] - [11]. More than that, Allport and Ross [5] revealed that those who have strong religious beliefs precisely have a low tolerance towards other individuals or groups. Moreover, that attitude is consistently held. Also found that such attitudes could occur due to the perspective developed in the activities of religious institutions is in-group-oriented perspective, not the perspective of togetherness. They also tend to support only the existence of the group (reference group), rather than participate outside the group [5] -[12].

\section{METHOD}

The main research variables are the frequencies of receiving the Dash of Dakwah Communications Message as the independent (X1) and the Behavior of Social Concern as the dependent variable (Y). Because the effects of dakwahcommunication as well as behavior of social concern are very likely also influenced by other factors, so in the test of the relations, the three moderator variables are: the frequency of Forwarding Dakwah Message Interpersonally (X2), the frequency of Using Mass Media (X3), and the Role of Reference Group (X4) were inserted.

The applied method is survey with the object of the study is the participants of dakwah activities (Recitation= local terminology) held by a dakwah organization of PersyarikatanMuhammadiyah and Qur'an Tafsir Council (MTA), residency of Surakarta.

The population is 1731 people that consisting of Muhammadiyah memberis 1085 people and MTA member is 646 people. Meanwhile, the number of sample was 414 people, divided into 260 people from Muhammadiyah and 154 people from the MTA. The number of sample units were assigned by using the stratified area proportional random sampling method, with $0.5 \%$ Alpha.Data was collected using a questionnaire instrument, with five scale of Likert.

Due to the relations of the influence involve a moderator variable, so the method used to test is Moderated Regression Analysis (MRA).

\section{RESULT}

MRA model servesto determine the function of moderator variables in the relation of the influence between independent variables and the dependent variables. The one, which wants to be known through this MRA test are: 1) how big the role or influence of each independent variable (X1) and X1 interaction with the moderator variable separately toward the dependent variable. It can be seen at the amount of the value t-test resulted, 2) the effect of the independent variable (X1) and $\mathrm{X} 1$ interaction with moderator variable together (simultaneously) towards dependent variable. For the second, it can be proven based on the results of the F-test.

\begin{tabular}{ccccc} 
Table 1. The Result of t-test & & & \\
\hline $\begin{array}{c}\text { Independent } \\
\text { Variables }\end{array}$ & $\begin{array}{c}\text { Dependent } \\
\text { Variable }\end{array}$ & t-test & Sig & Description \\
\hline$X 1$ & & -2.03 & .043 & Influenced \\
$X 1(X 2)$ & Social & 2.29 & .022 & Influenced \\
$X 1(X 3)$ & Concern (Y) & 4.57 & .000 & Influenced \\
$X 1(X 4)$ & & 2.40 & .017 & Influenced \\
\hline
\end{tabular}

Based on the comparison of the t-test value above, it can also be seen that the reference group (X3) has the greatest role to reinforce the influence of dakwah message dash (X1) toward behavior of social concern (Y).But the othermoderatorsvariable has lesser role.

Furthermore, it was tested the influence of the independent variable (X1) and X1 interaction with moderator variable simultaneously (together) toward the dependent variable.

Table 2. The Result of F-test

\begin{tabular}{ccccc}
\hline $\begin{array}{c}\text { Independent } \\
\text { Variables }\end{array}$ & $\begin{array}{c}\text { Dependent } \\
\text { Variabel }\end{array}$ & F-test & Significant & Description \\
\hline $\mathrm{X} 1$ & & & & \\
$\mathrm{X} 1(\mathrm{X} 2)$ & Social & 13.799 & 0.000 & Influenced \\
$\mathrm{X} 1(\mathrm{X} 3)$ & Concern (Y) & & & \\
$\mathrm{X} 1(\mathrm{X} 4)$ & & & & \\
\hline
\end{tabular}

F-test value produced is greater than the value of $\mathrm{F}$ table (13.799> 2,394), and a significant value is smaller than alpha $5 \% \quad(0.000<0.050)$. Therefore, it can be concluded that the variables of Dakwah Message Dash (X1) and X1 interaction with the moderator variables, simultaneously affect the variable of the Behavior of Social Concern (Y) with the level of mistakes at $5 \%$.

Meanwhile, to explain the enormous mutual influence can be based on the enormity of determinant square value (R2) as shown that Coefficient $R^{2}$ value obtained is amounted to 0.119 , then the enormity of the simultaneous effect as mentioned above is amounted to 0.119 , or approximately $11,9 \%$, and the remaining $88.1 \%$ 
is influenced by other factors outside of the variables studied.

The following discussion is about the form of the relations of the influence from the independent variable and the moderator variable toward dependent variable. The form of the relation of the influence which is meant is the form of positive or negative relations. For these needs, it can be seen in the coefficient of the results of the moderated regression analysis (MRA), as shown in Table 3.

Table 3: The Coefficient of Moderated Regression Analysis (MRA)

\begin{tabular}{|c|c|c|c|c|c|}
\hline \multicolumn{6}{|c|}{ Coefficients $^{\mathbf{a}}$} \\
\hline \multirow[t]{2}{*}{ Model } & \multicolumn{2}{|c|}{$\begin{array}{l}\text { Unstandardized } \\
\text { Coefficients }\end{array}$} & \multirow{2}{*}{$\begin{array}{c}\text { Standardized } \\
\text { Coefficients }\end{array}$} & \multirow{2}{*}{$\mathrm{t}$} & \multirow{2}{*}{ Sig } \\
\hline & B & Std. Error & & & \\
\hline 1 (constant) & 2.207 & .226 & & 9.745 & \\
\hline $\mathrm{X} 1$ & -.240 & .118 & .163 & -2.031 & .043 \\
\hline $\mathrm{X} 1(\mathrm{X} 2)$ & 029 & .012 & .135 & 2.293 & .022 \\
\hline X1(X3) & .071 & .015 & .315 & 4.576 & .000 \\
\hline X1(X4) & .033 & .014 & .135 & 2.407 & .017 \\
\hline
\end{tabular}

a. Dependent Variable: The Behavior of Social Concern (Y

Referring to the table above, the explanation can be obtained as follows: every moderator variable positivelyreinforces the influence of variable independent towards social concern behavior in positive trend; but dependence to the reference group variable has strongest role, then was followed by using media variable.It indicates that the more frequently respondents do to the moderator variables can increase more significantly the effect of dakwah message towards the behavior of social concern. That indeed the influence of dakwah message seems less real despite significant toward the level of social concern. This was proven through the t-test = 2.031 smaller than $\mathrm{t}$ table $=1.966$; though significant at alpha $5 \%(0.043<0.050$, but weakness.

\section{CONCLUSION}

The MRA test describes that the reference group and the mass media has the greatest role to form the attitudes and behaviors of social concern. It can suppose that the activity of dakwah has formed an exclusive. Regarding the role of media, it can be supposed that the content of message of dakwahis less touching the realities. Meanwhile, the content of media is more realistic, factual, and dramatic. Therefore, the materials of dakwah communication can be packed to be more touching to the realities and the needs of the society, and avoid the in- group and out-group thinking. One of the way to realize it is that utilizing the public issues presented by the mass media as a source of dakwah messages. In other words, the contents of dakwah message should not be only textual but also must be contextual to the social, cultural, economic, political realities which are running in society. In this way, dakwah activity could answer the problems experienced by the society and not just be "black and white and in the clouds".

\section{REFERENCES}

[1] M. Ilyas, Komunikasi Dakwah, kertas kerja pada Pelatihan KaderMubalig PUI Jawa Barat, Indonesia, 2010

[2] H. K. Sobur, mekanisme dakwah: suatu analisis berdasarkan filsafat Qur'ani, Jurnal Inovasi,2006.

[3] M.M. Schlitz, C. Vieten, \& E.M. Miller, Worldview Transformation and Development of Social Consciousness, Journal of Consciousness Studies, 2010.

[4] S.R. Greene, and M. Kamimura, Ties that bind: enhancedsocial awareness development through interaction with peers. Annual Meeting, of the Association for the Study of Higher Education, 2003.

[5] M.C. Nisbet, P. Moy, and D. Schenfele, Religion, Communication, and Social Capital. Paper presented at the Annual Meeting of the International Communication Association, 2003.

[6] R. Wuthenow, Mobilizing Civic Engagement: The Changing Impact of Religious Involvement, in: T. Skocpol and M.P Fiorina (Eds), Civic Management in American Democracy, 1999

[7] C.P. Gilbert, The Impact of Churches on Political Behavior: An Empirical Study, 1993

[8] T.G. Jelen, Political Christianity: A Contextual Analysis, American Journal of Political Science, 1992

[9] R. D. Putnam, Bowling alone: The collapse andrevival of American Community, 2000

[10] A. Greenberg, The Church and revitalization of Poltics and Community, Political Science Quarterly, 2000

[11] E.C. Uslaner, EC, Producing and Consuming Trust, Political Science Quarterly, 2000

[12] D.A. Scheufele and D.V. Shah, Personality strength and social capital: The role of dispositional and informational variables in the production of civic participation, Communication Research, 2000 